\title{
PERBEDAAN TINGKAT SIMTOM ANSIETAS DAN DEPRESI ANTARA PEKERJA SEKS KOMERSIAL YANG MENDERITA HIV/ AIDS DENGAN YANG TIDAK MENDERITA HIV/ AIDS
}

\author{
Rini Gusya Liza, Elmeida Effendy, Freddy Subastian
}

\begin{abstract}
Abstrak
Penelitian ini bertujuan untuk mengetahui perbedaan tingkat simtom ansietas dan depresi antara pekerja seks komersial (PSK) yang menderita HIV/ AIDS dengan yang tidak menderita HIV/ AIDS. Penelitian potong lintang, dengan nonprobability sampling, jenis cluster sampling. Tempat penelitian adalah di lokalisasi Kabupaten Bengkalis dan di klinik VCT RSUD Kecamatan Mandau, Kabupaten Bengkalis. Subjek penelitian adalah wanita yang bekerja sebagai PSK di lokalisasi PSK, kooperatif, bersedia diwawancara. Subjek berjumlah 96 orang PSK; 48 orang menderita HIV/ AIDS dan 48 tidak menderita HIV/ AIDS. Data tentang status HIV/ AIDS diambil dari laporan klinik VCT RSUD Kecamatan Mandau. Alat ukur yang digunakan adalah Hospital Anxiety and Depression Scale. Analisis data yang digunakan adalah uji Kolmogorov-Smirnov. Didapatkan proporsi ansietas pada seluruh PSK adalah $22.9 \%$, pada PSK yang menderita HIV/ AIDS $31.2 \%$ dan PSK tidak menderita HIV/ AIDS 14.6\%, sedangkan proporsi depresi pada seluruh PSK adalah 25\%, pada PSK yang menderita HIV/ AIDS 27.1\% dan PSK yang tidak menderita HIV/ AIDS 22.9\%. Tidak terdapat perbedaan yang bermakna tingkat simtom ansietas dan depresi antara pekerja seks komersial yang menderita HIV/ AIDS dengan yang tidak menderita HIV/ AIDS. Simpulan, didapatkan tingginya ansietas dan depresi pada keseluruhan PSK itu sendiri. Disamping menjadi seorang PSK ditambah lagi dengan menderita HIV/ AIDS akan menambah beratnya simtom ansietas dan depresinya.
\end{abstract}

Kata kunci: Ansietas, depresi, HIV/ AIDS, pekerja seks komersial

\begin{abstract}
The aims of this study is to determine the differences of anxiety and depression symptoms level between commercial sex workers who suffer HIV/AIDS with not suffer HIV/AIDS. Cross sectional study, using nonprobability sampling technique, the type is cluster sampling. Location is in red light district of commercial sex workers in Kabupaten Bengkalis and in VCT clinic of general hospital of Kecamatan Mandau Kabupaten Bengkalis. Subjects were women who worked as prostitutes in red light district, cooperative, willing to be interviewed. Sample size were 96 women, 48 suffer HIV/ AIDS and 48 not suffer HIVIAIDS. Data on HIV/ AIDS status are collected from the report of VCT clinic of general hospital of Kecamatan Mandau. Measuring instruments is the Hospital Anxiety and Depression Scale. Data analysis by using the Kolmogorov-Smirnov test. It was found the proportion of anxiety in all sex workers is $22.9 \%$, in sex workers who suffer HIV/ AIDS is $31.2 \%$ and in sex workers who not suffer HIV/ AIDS is $14.6 \%$. While the proportion of depression in all sex workers is $25 \%$, in sex workers who suffer HIV/ AIDS is $27.1 \%$ and in sex workers who not suffer HIV/ AIDS is $22.9 \%$. There was no significant differences the level of anxiety and depression symptoms between commercial sex workers who suffer HIV/ AIDS with not suffer HIV/ AIDS. In conclusion, we get the high proportion of anxiety and depression symptoms among commercial sex workers themselves. Beside to being a prostitute in addition to having HIV / AIDS will increase the severity of symptoms of anxiety and depression.
\end{abstract}

Keywords: anxiety, commercial sex workers, depression, HIV/ AIDS

Afiliasi Penulis: Departemen IImu Kedokteran Jiwa FK USU, Bagian IImu Kedokteran Jiwa FK Unand. Korespondensi : Rini Gusya Liza, jalan Bunga Lau no.17, Departemen Ilmu Kedokteran Jiwa RS. H. Adam Malik, Medan. Email: rinigusya@yahoo.com, Telp \HP : 08126651738 


\section{PENDAHULUAN}

Salah satu penyakit mematikan di dunia yang kemudian menjadi wabah internasional atau bencana dunia sejak pertama kehadirannya adalah HIV/AIDS (human immunodeficiency virus/acquired immunodeficiency syndrome). ${ }^{1} \quad$ Ditjen PPM \& PL Depkes RI melaporkan kasus HIV/AIDS di Indonesia secara kumulatif 1 April 1987 sampai dengan 1 Juni 2013 adalah total pengidap HIV sebanyak 108.600 orang, pengidap AIDS sebanyak 43.667 orang dan kematian sebanyak 8.340 orang. $^{2}$

Perilaku seksual yang berisiko, pasangan seks yang berganti-ganti dan tidak memakai kondom dalam melakukan aktivitas seksual, merupakan faktor risiko utama penularan HIV/AIDS. Seks anal juga merupakan faktor perilaku seksual yang memudahkan penularan HIV/AIDS. ${ }^{3}$ Pekerja seks komersial (PSK) diketahui menyebarkan penyakit AIDS akibat perilaku seks bebas tanpa pengaman (kondom). ${ }^{4}$

Seseorang yang diberitahu bahwa mengidap HIV-positif atau disebut juga ODHA (Orang dengan HIV/AIDS) dapat menjadi pengalaman yang membuat stres, menyakitkan dan traumatis. Berhadapan dengan kematian yang tak terelakkan, cepat atau lambat, dan stigma yang melekat membuat HIV/AIDS salah satu yang paling ditakuti dari semua penyakit. Hidup dengan HIV berarti harus mengatasi kombinasi dari berbagai macam tantangan psikologis disebabkan oleh ketakutan, kecemasan, kerugian, ketidakpastian, perasaan malu, bersalah, menyalahkan diri sendiri dan

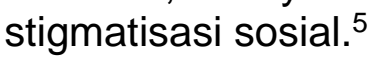

Sejumlah studi menunjukan bahwa terdapat prevalensi yang tinggi ansietas, gangguan mood, gangguan penyesuaian dengan gejala depresi, gangguan campuran ansietas dan depresi pada pasien HIV. Prevalensi depresi dan ansietas pada pasien HIV bervariasi, diketahui prevalensi depresi pada pasien HIV berkisar antara 15$40 \% .{ }^{6} \quad$ Penelitian yang dilakukan
Morrison dan kawan-kawan melaporkan prevalensi depresi pada wanita yang terinfeksi HIV adalah $19,4 \%$ gangguan depresi mayor dan 26\% gangguan ansietas. $^{7}$

Hospital anxiety and depression scale (HADS) adalah alat ukur self report yang secara spesifik dirancang untuk menilai dan menyaring ansietas dan depresi pada pasien dengan penyakit medis. Tidak adanya item somatik adalah keuntungan utama alat ukur ini dibandingkan alat ukur lainnya. HADS mewakili alat ukur self-report terbaik yang tersedia saat ini, terbukti valid dan andal menilai ansietas dan depresi pada pasien terinfeksi HIV. HADS terdiri dari 14 item, 7 item menilai ansietas dan 7 item menilai depresi. Alat ukur ini sederhana dan singkat untuk dilakukan sehingga mudah diimplementasikan dalam perawatan rutin pasien HIV. Karena terdapat tumpang tindih antara manifestasi HIV dengan gejala-gejala somatik dari ansietas dan depresi, sangat penting untuk menggunakan alat ukur yang tidak mengandung item somatik yang secara valid dan andal menilai keadaan psikologis pasien terinfeksi HIV. 8,9

Provinsi Riau adalah provinsi ke sembilan tertinggi jumlah kumulatif kasus AIDS dari tahun 1987 sampai dengan September 2012 di Indonesia, ${ }^{10}$ sedangkan Kabupaten Bengkalis merupakan Kabupaten/ Kota kedua tertinggi kasus HIV dan AIDS di Provinsi Riau. ${ }^{11}$ Jumlah kasus HIV di Propinsi Riau yang tercacat sampai dengan 1 Juni 2013 adalah 1503 kasus dan kasus AIDS sebanyak 859 kasus, ${ }^{2}$ sedangkan di Kabupaten Bengkalis sampai dengan Maret 2013 sebanyak 288 kasus. ${ }^{11}$ Kecamatan Mandau dan Kecamatan Pinggir berada di Kabupaten Bengkalis Provinsi Riau dilewati oleh jalur lintas timur Sumatera yang padat kendaraan seperti kendaraan roda empat, kendaraaan berat seperti bus, truk dan lain-lain, sehingga Kecamatan Mandau dan Kecamatan Pinggir menjadi tempat persinggahan kendaraan lalu lintas Sumatera. Selain 
itu di kedua Kecamatan ini terdapat perusahaan penambangan minyak PT. Chevron Pacific Indonesia (CPI) yang memiliki ratusan anak perusahaan, sehingga daerah ini dihuni oleh banyak pendatang yang tidak tinggal menetap yang merupakan laki-laki berisiko tinggi. Laki-laki berisiko tinggi (LBT) yaitu jutaan laki-laki, pada umumnya usia muda/usia reproduktif yang bekerja terpisah dari keluarga maupun tempat dimana ia biasa bermasyarakat (bahkan sering berpindah-pindah), antara lain mereka yang bekerja di bidang pertambangan, pertanian dan perkebunan, perikanan, konstruksi (jalan, jembatan, pelabuhan, dan bandar udara), kehutanan, dan transportasi jarak jauh (biasanya transportasi darat atau antar pulau) dan lain-lain. Mereka pada umumnya cenderung melakukan "seks berisiko" maupun perilaku berisiko lain seperti mengkonsumsi minuman keras, narkotika dan obat-obat terlarang dan lain-lain, sehingga berisiko tinggi untuk penularan HIV dan penyakit lainnya. ${ }^{4}$

Seiring dengan itu berdiri lokalisasi PSK, panti pijat (okup), tempat hiburan seperti bar, karaoke, warung remang-remang dan penginapan-penginapan baik besar maupun kecil. Di Kecamatan Mandau dan Kecamatan Pinggir terdapat lebih dari 300 orang PSK yang tersebar di lokalisasi dan tempat hiburan, pengobatan tradisonal okup, bar dan lain-lain. Kasus HIV/AIDS pada PSK yang tercacat di klinik VCT RSUD Kecamatan Mandau sampai dengan Maret 2013 sebanyak 51 kasus. ${ }^{12}$ Penelitian ini bertujuan untuk mengetahui perbedaan tingkat simtom ansietas dan depresi antara PSK yang menderita HIV/AIDS dengan PSK yang tidak menderita HIV/AIDS. Manfaat penelitian adalah dengan diperolehnya tingkat simtom ansietas dan depresi pada PSK yang menderita HIV/AIDS dan PSK yang tidak menderita HIV/AIDS maka dapat menjadi pedoman dan masukan bagi tenaga kesehatan dan kedokteran jiwa bahwa PSK perlu juga mendapat perhatian tentang kesehatan jiwanya agar tidak timbul gangguan jiwa yang lebih berat.

\section{METODE}

Penelitian ini adalah penelitian potong lintang. Tempat penelitian adalah di lokalisasi PSK dan di okup di Kecamatan Mandau, di Kecamatan Pinggir dan di klinik VCT (Voluntary Counseling Test) Rumah Sakit Umum Daerah, Kecamatan Mandau, Kabupaten Bengkalis. Waktu penelitian adalah 1 Maret 201330 Maret 2013.

Populasi penelitian adalah wanita PSK yang bekerja di lokalisasi PSK dan di okup di Kecamatan Mandau dan di Kecamatan Pinggir Kabupaten Bengkalis pada 1 Maret 2013-30 Maret 2013. Subjek penelitian adalah wanita PSK yang memenuhi kriteria inklusi. Cara pengambilan sampel dengan non probability sampling jenis cluster sampling. Besar sampel minimal untuk masingmasing kelompok adalah 48 orang, total 96 orang. Kriteria inklusi antara lain: wanita yang bekerja sebagai PSK, bekerja di lokalisasi PSK dan di okup yang ada di Kecamatan Mandau dan Kecamatan Pinggir, Kabupaten Bengkalis, kooperatif dan dapat diwawancarai, bersedia ikut serta dalam penelitian. Kriteria eksklusi antara lain: menderita penyakit medis umum seperti penyakit kardiovaskuler, penyakit hepatobiliar, penyakit gastrointestinal dan lain-lain (Selain HIV/AIDS), gangguan psikiatri sebelumnya misalnya gangguan psikotik, gangguan ansietas dan gangguan depresi, riwayat penggunaan Napza kecuali rokok dan alkohol.

Peneliti berkunjung ke lokalisasi dan ke okup bersamaan dengan jadwal kunjungan rutin staf dari klinik VCT. Staf klinik VCT datang ke lokalisasi dan ke okup beberapa kali dalam sebulan, sekali kunjungan untuk satu lokasi untuk mengambil sampel darah dan sekret vagina wanita-wanita PSK disana untuk diperiksa di laboratorium, melakukan penyuluhan tentang penggunaan kondom, bahaya infeksi HIV/AIDS dan lain- 
lain. Setiap PSK diwajibkan dilakukan pemeriksaan HIV setiap tiga bulan. Sebelumnya peneliti mengambil data sekunder dari klinik VCT yaitu data-data dari hasil pemeriksaan HIV/AIDS sebelumnya untuk mendapatkan nama-nama PSK yang sudah pernah diperiksa dan sudah diberitahu bahwa mereka menderita infeksi HIV/AIDS dan yang dinyatakan tidak menderita infeksi HIV/AIDS. Peneliti akan menyesuaikan data sekunder yang didapat sebelumnya tentang nama-nama PSK yang menderita HIV/ AIDS dengan yang tidak menderita HIV/ AIDS, dan juga menanyakan langsung kepada responden. Peneliti melakukan wawancara dan memberikan kuesioner di lokalisasi dan di okup di Kecamatan Mandau dan di Kecamatan Pinggir kepada PSK yang menderita HIV/AIDS dengan yang tidak menderita HIV/AIDS. Kepada kedua kelompok ini peneliti menyerahkan kuesioner untuk diisi dan apabila responden tidak bisa tulis baca maka kuesioner diisi dengan melakukan wawancara terpimpin. Kuesioner harus diisi lengkap sudah diisi lengkap dan dikembalikan kepada peneliti. Sebelum melakukan wawancara, peneliti terlebih dahulu mengadakan pendekatan terhadap subjek yang akan diteliti dengan cara memberikan penjelasan mengenai tujuan dan manfaat serta pentingnya peran serta subjek dalam membantu peneliti mendapatkan data yang diinginkan. Subyek penelitian akan diberikan kuesioner "Hospital anxiety and depression scale" yang sudah diterjemahkan ke bahasa Indonesia oleh Pusat Bahasa Universitas Sumatera Utara. Kuesioner HADS masing-masing memiliki 7 pertanyaan yang terbagi atas poin $A$ untuk ansietas (yaitu pertanyaan nomor $1,3,5,7,9,11$ dan 13) serta poin $D$ untuk depresi (yaitu pertanyaan nomor $2,4,6,8,10,12$ dan 14). Skor total 0 sampai 7 menunjukkan rentang normal, 8 sampai 10 menunjukkan hampir abnormal (borderline) dan 11 atau lebih menunjukkan adanya gangguan mood. Kemudian subjek penelitian mengisi kuesioner tersebut sesuai dengan keadaan perasaannya sekarang. Peneliti juga dibantu oleh staf di klinik VCT yang sudah dilatih menggunakan kuesioner. Jumlah kuesioner yang akan diisi adalah sebanyak 96 buah kepada 96 subjek penelitian sesuai dengan besar sampel penelitian. Setelah semua kuesioner diisi dilakukan pengolahan data dilakukan editing, koding, tabulasi dan análisis data. Data penelitian dianalisis menggunakan uji Kolmogorov-Smirnov.

Semua subjek penelitian akan diminta persetujuan yang terlebih dahulu diberi penjelasan sebelum diikutsertakan sebagai subjek penelitian. Penelitian ini telah disetujui oleh Komite Etika Penelitian di Fakultas Kedokteran Universitas Sumatera Utara Medan.

\section{HASIL DAN PEMBAHASAN}

Dari keseluruhan subjek terlihat pada tabel 1 didapatkan status perkawinan PSK terbanyak adalah belum menikah, sebahagian besar berpendidikan rendah, perokok dan peminum alkohol. Proporsi ansietas pada PSK yang menderita HIV/AIDS yaitu $31,2 \%$ dan proporsi ansietas pada PSK yang tidak menderita HIV/AIDS yaitu 14,6\%. Proporsi PSK yang mengalami ansietas dari total jumlah PSK yang diteliti adalah $22,9 \%$.

Hasil uji Kolmogorov-Smirnov didapatkan hasil tidak terdapat perbedaan tingkat simtom ansietas antara PSK yang menderita HIV/ AIDS dengan PSK yang tidak menderita HIV/ AIDS $(p=0,161)$.

Didapatkan proporsi depresi pada PSK yang menderita HIV/ AIDS yaitu $27,1 \%$ dan proporsi depresi pada PSK yang tidak menderita HIV/ AIDS yaitu $22,9 \%$. Proporsi PSK yang mengalami depresi dari total jumlah PSK yang diteliti adalah 25\%. Hasil uji KolmogorovSmirnov didapatkan hasil tidak terdapat perbedaan tingkat simtom depresi antara PSK yang menderita HIV/ AIDS dengan PSK yang tidak menderita HIV/ AIDS $(p=1,0)$. 
Tabel 1. Status sosiodemografik subjek penelitian

Status sosiodemografik $\quad \mathrm{n}(\%)$

1 Umur \{Rata-rata \pm SD $29 \pm 5.02$ (tahun)\}

2 Status perkawinan

Menikah

Belum Menikah Janda

3 Tingkat pendidikan

$$
\begin{aligned}
& \text { Tinggi } \\
& \text { Menengah } \\
& \text { Rendah }
\end{aligned}
$$

4 Merokok

$$
\text { Tidak Perokok }
$$

Perokok

5 Meminum alkohol

Tidak Pernah

Peminum Alkohol

4 Diagnosis AIDS

2 (2\%)

$54(56,3 \%)$

$40(41,7 \%)$

$1(1 \%)$

$30(31,3 \%)$

$65(67,7 \%)$

$41(42,7 \%)$

$55(57,3 \%)$

$16(16,67 \%)$

$80(83.3 \%)$

$1(1,04 \%)$

5 HADS ansietas (Rata-rata $\pm \quad 8,91 \pm 5.39$ $\mathrm{SD})$

6 HADS depresi (Rata-rata $\pm \quad 8,11 \pm 5.53$ $\mathrm{SD})$

Keterangan: SB = Simpangan baku menderita HIV/AIDS. Pada penelitian ini didapatkan proporsi ansietas pada PSK yang menderita HIV/AIDS adalah $31,2 \%$, hasil ini lebih rendah dibandingkan penelitian oleh Tostes dan kawan-kawan mendapatkan proporsi ansietas pada pasien HIV/AIDS menggunakan HADS adalah $36,8 \% .{ }^{13}$ Hasil penelitian ini lebih tinggi dibanding penelitian yang dilakukan oleh Pappin dan kawan-kawan mendapatkan proporsi ansietas pada pasien HIV/AIDS yang telah mendapatkan terapi antiviral yaitu 30,6\%, hal ini kemungkinan efek pemakaian antiviral sehingga tingkat ansietas pasien HIV/AIDS berkurang. ${ }^{14}$

Pada penelitian ini didapatkan proporsi depresi pada PSK yang menderita HIV/AIDS adalah $27,1 \%$, hasil ini lebih rendah daripada penelitian oleh Tostes dan kawan-kawan mendapatkan proporsi depresi pada pasien terinfeksi HIV/AIDS mendapatkan 30,3\%, juga lebih rendah dibandingkan penelitian oleh Sale dan Gadanya mendapatkan pro-

\begin{tabular}{|c|c|c|c|c|c|c|c|}
\hline \multirow[t]{2}{*}{ HADS-A } & \multicolumn{2}{|c|}{$\begin{array}{l}\text { PSK dengan HIV/ } \\
\text { AIDS }\end{array}$} & \multicolumn{2}{|c|}{$\begin{array}{l}\text { PSK tanpa HIV/ } \\
\text { AIDS }\end{array}$} & \multicolumn{2}{|l|}{ Total } & \multirow[t]{2}{*}{$\begin{array}{l}\text { Nila } \\
\mathrm{p}\end{array}$} \\
\hline & frekuensi & $\%$ & frekuensi & $\%$ & frekuensi & $\%$ & \\
\hline Normal & 27 & 56,3 & 38 & 79.2 & 65 & 67,7 & 0,16 \\
\hline Boderline & 6 & 12.5 & 3 & 6.2 & 9 & 9,4 & \\
\hline ansietas & 15 & 31.2 & 7 & 14.6 & 22 & 22,9 & \\
\hline Total & 48 & 100 & 48 & 100 & 96 & 100 & \\
\hline
\end{tabular}
porsi depresi pada pasien HIV/AIDS adalah $39,91 \%$.

Tabel 2 .Distribusi subjek penelitian berdasarkan tingkat simtom ansietas

Tabel 3. Distribusi subjek penelitian berdasarkan tingkat simtom depresi

\begin{tabular}{llllllll}
\hline HADS-D & \multicolumn{2}{l}{$\begin{array}{l}\text { PSK dengan HIV/ } \\
\text { AIDS }\end{array}$} & $\begin{array}{l}\text { PSK tanpa } \\
\text { HIV/AIDS }\end{array}$ & Total & \multirow{2}{*}{$\begin{array}{l}\text { Nilai } \\
\text { p }\end{array}$} \\
\cline { 2 - 7 } & frekuensi & $\%$ & frekuensi & $\%$ & frekuensi & $\%$ & \\
\hline Normal & 32 & 66,6 & 35 & 72,9 & 67 & 69,8 & 1,0 \\
Boderline & 3 & 6,3 & 2 & 4,2 & 5 & 5,2 & \\
depresi & 13 & 27,1 & 11 & 22,9 & 24 & 25 & \\
\hline Total & 48 & 100 & 48 & 100 & 96 & 100 & \\
\hline
\end{tabular}

Penelitian ini merupakan penelitian yang membandingkan tingkat simtom ansietas dan depresi antara pekerja seks komersial (PSK) yang menderita HIV/AIDS dengan PSK yang
Tetapi penelitian ini lebih tinggi daripada penelitian yang dilakukan oleh Ndu dkk, mendapatkan proporsi depresi pada pasien HIV adalah $21,3 \%{ }^{13,15,16}$ 
Hasil penelitian ini jauh lebih rendah dari pada penelitian yang dilakukan oleh Alegria dan kawan-kawan yang juga meneliti simtom-simtom depresi pada PSK yang menderita HIV tetapi menggunakan alat ukur yang berbeda yaitu Center for Epidemiologic Studies Depression Scale, mereka mendapatkan $70 \%$ PSK yang menderita HIV mengalami depresi. ${ }^{17}$

Proporsi depresi dan proporsi ansietas pada PSK yang menderita HIV/AIDS lebih tinggi dibandingkan pada PSK yang tidak mendeita HIV/AIDS. Selain menjadi seorang PSK ditambah dengan mempunyai penyakit HIV/AIDS akan menambah beratnya simtom anisetas dan depresinya, karena proporsi ansietas dan depresi pada PSK sendiri prevalensinya juga tinggi, pada penelitian ini proporsi tingkat simtom ansietas pada seluruh PSK adalah 22,9\% dan tingkat simtom depresi didapatkan $25 \%$.

Dari penelitian didapatkan proporsi PSK yang menderita HIV/AIDS tertinggi pada usia $20-<30$ tahun, hal ini sesuai dengan laporan Ditjen PP \& PL Kemenkes RI pada tahun 2013 bahwa proporsi kasus HIV/AIDS tertinggi pada golongan umur 20-29 tahun. ${ }^{2}$

Dari hasil penelitian $67,7 \%$ PSK memiliki tingkat pendidikan yang rendah. Penyebab seseorang menjadi PSK salah satunya adalah karena rendahnya tingkat pendidikan dan kemiskinan sehingga tidak punya pilihan pekerjaan yang layak. ${ }^{18}$

Hasil pengujian statistik didapatkan tidak terdapat perbedaan tingkat simtom ansietas dan depresi antara PSK yang menderita HIV/ AIDS dengan PSK yang tidak menderita HIV/ AIDS, hal ini mungkin disebabkan pada PSK sendiri tingkat simtom ansietas dan depresinya juga tinggi. Gangguan ansietas dan depresi pada PSK antara lain disebabkan oleh stigma, diskriminasi dan isolasi masyarakat terhadap PSK, kekerasan fisik ataupun psikis yang didapatkan PSK baik dari klien atau dari pemilik bar dan tempat hiburan dan rendahnya perlindungan hukum pada PSK. Ansietas dapat juga timbul oleh karena praktek PSK itu sendiri adalah illegal sehingga dapat terjerat oleh hukum dan ditangkap oleh aparat keamanan. Selain itu anisetas pada PSK terjadi karena ketakutan dan kecemasan akan mendapatkan penyakit menular seksual seperti HIV. 17-20

Kelemahan penelitian ini adalah sulit untuk mengeksklusikan gangguan mental dan perilaku akibat penggunaan alkohol dan rokok, disebabkan umumnya gaya hidup wanita di bar dan di lokalisasi tidak terlepas dari alkohol dan rokok.

Perlu penelitian lebih lanjut tentang penyebab tingginya simtom anisetas dan depresi pada PSK dan penelitian untuk mengetahui peran antiviral HIV terhadap tingkat simtom ansietas dan depresi.

\section{SIMPULAN}

Proporsi tingkat simtom ansietas dan depresi lebih tinggi pada PSK yang menderita HIV/AIDS dibandingkan PSK tidak menderita HIV/AIDS. Tidak terdapat perbedaan tingkat simtom ansietas dan depresi antara ODHA dengan bukan ODHA pada pekerja seks komersial.

\section{DAFTAR RUJUKAN}

1. Arriza BK, Dewi EK, Kaloeti DVS. Memahami rekonstruksi kebahagiaan pada orang dengan HIV/ AIDS (ODHA). Jurnal Psikologi Undip. 2011;10(2): 153-62

2. Kementrian Kesehatan RI. Direktorat jenderal pengendalian dan penyehatan lingkungan. Statistik Kasus HIV/AIDS di Indonesia-Laporan s/d Juni 2013. Ditjen PP \& PL Kemenkes RI. 2012:1-3

3. Laksana ASD, Lestari DWD. Faktor-faktor risiko penularan HIV/AIDS pada laki-laki dengan orientasi seks heteroseksual dan homoseksual di purwokerto. Mandala of Health 2010;4(2),113-23

4. Komisi Penanggulangan AIDS Nasional. Upaya Penanggulangan HIV dan AIDS di Indonesia 2006-2011: Laporan 5 Tahun Pelaksanaan Peraturan Presiden No. 75/2006 tentang Komisi Penanggulangan AIDS Nasional. Oktober 2011. 
5. Plattner IE, Meiring N. Living with HIV: The psychological relevance of meaning making. AIDS Care 2006;18(3):241-5

6. Koutsilieri E, Scheller C, Sopper S, Meulen VT, Riederer P. Psychiatric complications in human immunodeficiency virus infection. Journal of NeuroVirology 2002;8(suppl.2):129-33

7. Morrison MF, Petitto JM, Have TT, Gettes $D R$, Chiappini MS, Weber AL, et al. Depressive and anxiety disorders in women with HIV infection. Am J Psychiatry 2002;159:789-96

8. Savard J, Laberge B, Gauthier JG, Ivers $H$, Bergeron MG. Evaluating anxiety and depression in HIV-infected patients. J Pers Assess 1998 Dec;71(3):349-67.

9. Wouters E, Booysen FLR, Ponnet K, Loon FBV. Wording effects and the factor structure of the hospital anxiety \& depression scale in HIV/AIDS patients on antiretroviral treatment in south africa. PloS ONE 2012:7(4);1-10

10. Kementrian Kesehatan RI. Direktorat jenderal pengendalian dan penyehatan lingkungan. Laporan perkembangan HIV AIDS triwulan III tahun 2012. Jakarta; Ditjen PP \& PL Kemenkes RI. November 2012:1-80

11. Harahap SW. AIDS di Kabupaten Bengkalis, Riau, ditanggulangi dengan pembagian kondom. 12 Juni 2013. (Diunduh Maret 2013). Tersedia dari: http://www. aidsindonesia.com

12. Laporan Klinik VCT RSUD Kecamatan Mandau. Maret 2013.

13. Tostes MA, Chalubb M, Botegac NJ. Psychological and socio-medical Aspects of AIDS/HIV. AIDS care 2004;16(2):177-86
14. Pappin M, Wouters E, Booysen FLR. Anxiety and depression amongst patient enrolled in a public sector antiretroviral treatment programme in South Africa: a crosssectional study. BMC Public Health 2012;12(244);1-9

15. Sale S, Gadanya M. Prevalence and factor association with depression HIV/ AIDS patients age 15-25 years at Amino Kano teacing hospital Nigeria. Journal of child and adolescent mental health 2008:20(2);95-99

16. Ndu AC, Arinze-Onyia SU, Aguwa EN, Obi IE. Prevalence of depression and role of support groups in its management: A study of adult HIV/AIDS patients attending HIV/AIDS Clinic in a tertiary health facility in South-eastern Nigeria. Journal of Public Health and Epidemiology 2011;3(4),182-6

17. Alegria M, Vera M, Freeman $D H$, Robles $R$, Santos MC, Rivera CL. HIV infection, risk behaviors, and depressive symptoms among Puerto Rican sex workers. American Journal of public health 1994:84(12);2000-2

18. Baker LM, Case p, General health problems of inner-city sex workers: a pilot study. J Med Libr Assoc 2003:91(1);67-71

19. Rossler W, Koch U, Lauber C, Hass AK, Altwegg M, Ajdacic-Gross V, Landolt K. The mental health of female sex workers. Acta Psychiatr Scand 2010:1-10

20. Hong $Y$, Xiaoming $L$, Fang $X$, Zhao $R$. Depressive symptoms and condom use with clients among female sex workers in China. Sex Health 2007 June;4(2):99-104. 